\title{
Antibiotic Sensitivity in UTI among Diabetic Pregnant Women
}

\author{
NAHER N ${ }^{1}$, BEGUM $F^{2}$, HASHEM N ${ }^{3}$
}

\begin{abstract}
Background: Urinary tract infection (UTI) is common during pregnancy and especially so in pregnant patients with diabetes mellitus. The emergence of drug resistance and particularly the extended spectrum Beta-lactamase production by Escherechia Coli and Methicillin resistance in staphylococci, limits the choice of anti-microbials.
\end{abstract}

Method: A cross-sectional study was conducted on 50 pregnant women with sign and symptoms of UTI in the Department of Obstetrics and Gynaecology, BIRDEM general Hospital-2 from January to June 2017. The objectives of the study were to determine the presence and type of pathogens found in pregnant diabetic women presenting with features of urinary tract infection, and to analyze their antibiotic sensitivity pattern. Clean catch midstream urine samples were collected using standard procedure and culture and sensitivity was done following standard bacteriological method.

Results: Mean age of the study subjects was $29.84 \pm 5.29 \mathrm{yrs;} 48 \%$ were in third trimester of pregnancy; 52\% had Gestational Diabetes Mellitus (GDM) and 48\% had Diabetes Mellitus (DM). Out of fifty pregnant women, thirty eight (76.0\%) study subjects had positive growth. Of them, Escherechia coli was found in $57.9 \%$ cases, Klebsiella in $21.1 \%$, Staphylococcus aureus in $7.9 \%$, Enterococcus and Pseudomonas aeruginosa each in $2.6 \%$ case. Amikacin was found to be sensitive to $100 \%$ cases of E. Coli, Klebsiella \& Enterococcus but $100 \%$ resistant to Streptococcus.

Conclusion: In this study, E. Coli was the most common organisms causing UTI, which is less susceptible to conventional oral antibiotics but more susceptible to amikacin. So carefull drug selection is required for successful outcome in UTI.

Key words: Pregnancy UTI, Urinary Tract Infection, UTI and GDM

\section{Introduction:}

Urinary tract infection is a common health problem among women due to shorter urethra, closer proximity to the vagina and pathogen entry facilitated by sexual activity ${ }^{1,2}$. It is estimated that one in three women of child-bearing age contracts UTI, which may manifest symptoms or remain asymptomatic ${ }^{3}$. Prevalence of symptomatic UTI in Diabetic patient was $67 \%$ (65\% in GDM and $8.6 \%$ in PGDM $)^{4}$. When compared with non-pregnant women and pregnant women have a two fold increase in risk of being affected with symptomatic UTIUTI. This is due to the urinary stasis during pregnancy caused by anatomical and physiological changes in the urinary tract, such as pressure effect by the gravid uterus on the ureters and the relaxant effect of progesterone on the urinary tract muscles 5 .

The prevalence of S UTI during pregnancy in nondiabetic women varies from $3 \%$ to $10.1 \%$ while in diabetic pregnant women it can be as high as $27.6 \%{ }^{6-7}$. The UTI could be either lower UTI, which could be either asymptomaticbacteriuria or acute

1. Senior Medical Officer, BIRDEM General Hospital, Dhaka, Bangladesh

2. Professor \& Head of Department of Obstetrics \& Gtnaecology, BIRDEM General Hospital \& Ibrahim Medical College, Dhaka, Bangladesh

3. Assistant Registrar, BIRDEM General Hospital, Dhaka, Bangladesh

Address of Correspondence: Dr. Nurun Naher, FCPS (Obs \& Gynae) Senior Medical Officer, BIRDEM General Hospital, Dhaka, Bangladesh. Email: nurunnahernayan@gmail.com Tel: 01711339359 
cystitis, or the less common but more serious acute pyelonephritis. During pregnancy, there are physiological and anatomical changes that occur in the urinary tract which increases the incidence of asymptomatic bacteriuria and its progression to either acute cystitis and/or acute pyelonephritis.

Even though the precise mechanisms for the predilection of pathogens to cause UTI in diabetics remains unclear, a few research have revealed that the reasons could be immunological impairments such as impaired migration of neutrophils, intracellular killing, phagocytosis, defects in the local urinary cytokine secretions (IL-8, IL-6), increased adherence of the microorganisms to the uroepithelial cells, partly due to a changed and lowered Tamm Horsfall protein, and chemotaxis of polymorphonuclear leukocytes from diabetic patients and neuropathic complications such as impaired bladder emptying, as a result static pools of urine will remain in the bladder. In addition, a higher glucose concentration in the urine acts as a favorable culture medium for pathogenic bacteria and promotes rapid bacterial colonization and growth 8,9 .

Escherechia coli is the predominant uropathogenfound in UTI (cyctitis and pyelonephritis) in approximately $70-90 \%$ of cases. Other organisms responsible for UTI includes streptococcus (10\%), Klebsiella and enterobactor species (3\% each) and proteus an staphylocoous ( $2 \%$ each), saprophyticus. The bacteria with their sensitivity to various antimicrobial agents vary from place to place and in the same place from time to time ${ }^{10}$. The aims of this study were to identify organisms responsible for UTI in diabetic pregnant women.

\section{Methods:}

A total of 50 urine samples from pregnant women with GDM or DM at different gestational ages who presented with clinical features of UTI were processed for the isolation of the uropathogen and treated with antibiotics namely ciprofloxacine, amikacin, ceftriaxone, cefuroxime, gentamicin, nitrofurantoin, penicillin, amoxyclav, vancomycin. Clean catch midstream urine was collected in a sterile container maintaining sterility and was sent to the laboratory immediately. Informed written consent was obtained. The culture and sensitively was done following the standard bacteriological method.

\section{Results:}

Mean + SD age of study subjects was $29.84+5.29$ yrs; $30 \%$ patients were of age group $<25$ years; 73
;32\% were of $26-30 \mathrm{yrs}$ age: $20 \%$ were in age group $31-35$ yrs and $18 \%$ were $>35$ years age (table- 1 ). Highest frequently of occurrence of UTI was in third trimester $(45 \%)$, followed by second trimester $(44 \%)$ and only $8 \%$ cases were in first trimester (table 2). GDM patients were $52 \%$ and DM patients were $48 \%$ among the patients with symptoms of UTI, but among then $4 \%$ also had anemia (table-3).

Culture was positive in $76 \%(n=38)$ cases (table-4). A positive culture percentage of $48 \%$ was obtained with highest urinary tract infection in the third trimester gestational age. Among the uropathogens isolated, E. coli was found in $57.9 \%$ cases, Klebsiella in $21.1 \%$ cases, Streptpcoccus in $7.9 \%$ cases, Staphylococcus aureus in $7.9 \%$ cases, Enterococcus in $2.6 \%$ cases and Pseudomonas aeruginosa in similar number of cases. Amikacin was found sensitive to $100 \%$ cases in E. coli, Klebsiella and Enterococus but $100 \%$ resistant in Streptococcus.

Table-I

Distribution of the study subjects according to age $(n=50)$

\begin{tabular}{lcc}
\hline Age (years) & Frequency $(\mathrm{n})$ & Percentage \\
\hline $22-25$ & 15 & 30.0 \\
$26-30$ & 16 & 32.0 \\
$31-35$ & 10 & 20.0 \\
$>35$ & 9 & 18.0 \\
Total & 50 & 100.0 \\
Mean \pm SD & $29.84 \pm 5.29$ & \\
\hline
\end{tabular}

Table-II

Distribution of the study subjects according to trimesters $(n=50)$

\begin{tabular}{lcc}
\hline Trimesters & Frequency $(\mathrm{n})$ & Percentage \\
\hline $1^{\text {st }}$ & 4 & 8.0 \\
$2^{\text {nd }}$ & 22 & 44.0 \\
$3^{\text {rd }}$ & 24 & 48.0 \\
Total & 50 & 100.0 \\
\hline
\end{tabular}

Table-III

Distribution of the study subjects according to trimesters $(n=50)$

\begin{tabular}{lcc}
\hline Co-morbidities & Frequency $(\mathrm{n})$ & Percentage \\
\hline DM & 22 & 44.0 \\
GDM & 26 & 52.0 \\
DM with anemia & 2 & 4.0 \\
\hline
\end{tabular}




\section{Table-IV}

Distribution of the study subjects according to growth and type of organism $(n=50)$

\begin{tabular}{lcc}
\hline Growth & Frequency (n) & Percentage \\
\hline Positive & 38 & 76.0 \\
Escherichia coli & 22 & 57.9 \\
Klebsiella & 8 & 21.1 \\
Streptococcus & 3 & 7.9 \\
Staphylococcus aureus & 3 & 7.9 \\
Enterococcus & 1 & 2.6 \\
Pseudomonas aeruginosa & 1 & 2.6 \\
\hline
\end{tabular}

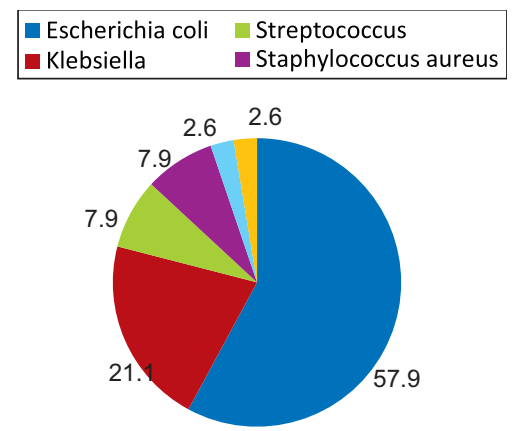

Fig.-1: Distribution of study subjects according to type of organism $(n=100)$

Table-V

Sensitivity and resistant pattern of antibiotic in different organisam

\begin{tabular}{|c|c|c|c|c|c|c|c|}
\hline Antibiotic/ Organism & & $\begin{array}{c}\text { Escherichia } \\
\text { coli }\end{array}$ & Klebsiella & Streptococcus & Enterococcus & $\begin{array}{c}\text { Staphylococcus } \\
\text { aureus } \\
\end{array}$ & $\begin{array}{c}\text { Pseudomonas } \\
\text { aeruginosa }\end{array}$ \\
\hline \multirow[t]{2}{*}{ Amikacin } & $\mathrm{S}$ & $12(100.0)$ & $5(100.0)$ & $0(0.0)$ & $1(100.0)$ & $0(0.0)$ & $0(0.0)$ \\
\hline & $\mathrm{R}$ & $0(0.0)$ & $0(0.0)$ & $3(100.0)$ & $0(0.0)$ & $0(0.0)$ & $0(0.0)$ \\
\hline \multirow[t]{2}{*}{ Amoxicillin } & $S$ & $3(37.5)$ & $0(0.0)$ & $2(100.0)$ & $0(0.0)$ & $0(0.0)$ & $0(0.0)$ \\
\hline & $\mathrm{R}$ & $5(62.5)$ & $1(100.0)$ & $0(0.0)$ & $0(0.0)$ & $1(100.0)$ & $1(100.0)$ \\
\hline \multirow[t]{2}{*}{ Ampicillin } & $S$ & $1(50.0)$ & $0(0.0)$ & $1(100.0)$ & $0(0.0)$ & $0(0.0)$ & $0(0.0)$ \\
\hline & $\mathrm{R}$ & $1(50.0)$ & $0(0.0)$ & $0(0.0)$ & $0(0.0)$ & $0(0.0)$ & $0(0.0)$ \\
\hline Azithromycin & $S$ & $2(100.0)$ & $0(0.0)$ & $2(100.0)$ & $0(0.0)$ & $0(0.0)$ & $0(0.0)$ \\
\hline \multirow[t]{2}{*}{ Cefixime } & $S$ & $4(36.4)$ & $2(50.0)$ & $0(0.0)$ & $0(0.0)$ & $1(50.0)$ & $1(100.0)$ \\
\hline & $\mathrm{R}$ & $7(63.6)$ & $2(50.0)$ & $0(0.0)$ & $0(0.0)$ & $1(50.0)$ & $0(0.0)$ \\
\hline \multirow[t]{2}{*}{ Ceftazidime } & $S$ & $4(36.4)$ & $2(50.0)$ & $0(0.0)$ & $0(0.0)$ & $0(0.0)$ & $0(0.0)$ \\
\hline & $\mathrm{R}$ & $7(63.6)$ & $2(50.0)$ & $2(100.0)$ & $0(0.0)$ & $1(100.0)$ & $1(100.0)$ \\
\hline \multirow[t]{2}{*}{ Ceftriaxone } & $S$ & $5(41.7)$ & $6(100.0)$ & $2(100.0)$ & $0(0.0)$ & $0(0.0)$ & $1(100.0)$ \\
\hline & $\mathrm{R}$ & 7 (58.3) & $0(0.0)$ & $0(0.0)$ & $0(0.0)$ & $1(100.0)$ & $0(0.0)$ \\
\hline \multirow[t]{2}{*}{ Cefuroxime } & $S$ & $4(57.1)$ & $1(100.0)$ & $0(0.0)$ & $0(0.0)$ & $1(100.0)$ & $0(0.0)$ \\
\hline & $\mathrm{R}$ & 3 (42.9) & $0(0.0)$ & $0(0.0)$ & $0(0.0)$ & $0(0.0)$ & $1(100.0)$ \\
\hline \multirow[t]{2}{*}{ Ciprofloxacin } & $S$ & $6(66.7)$ & $2(40.0)$ & $3(100.0)$ & $1(100.0)$ & $1(100.0)$ & $0(0.0)$ \\
\hline & $\mathrm{R}$ & $3(33.3)$ & $3(60.0)$ & $0(0.0)$ & $0(0.0)$ & $0(0.0)$ & $0(0.0)$ \\
\hline Cloxacillin & $S$ & $1(100.0)$ & $0(0.0)$ & $0(0.0)$ & $0(0.0)$ & $0(0.0)$ & $0(0.0)$ \\
\hline Colistin & $S$ & $4(100.0)$ & $3(100.0)$ & $0(0.0)$ & $0(0.0)$ & $0(0.0)$ & $0(0.0)$ \\
\hline \multirow[t]{2}{*}{ Co-trimoxazole } & $S$ & $3(50.0)$ & $0(0.0)$ & $1(100.0)$ & $0(0.0)$ & $1(100.0)$ & $1(100.0)$ \\
\hline & $\mathrm{R}$ & $3(50.0)$ & $2(100.0)$ & $0(0.0)$ & $1(100.0)$ & $0(0.0)$ & $0(0.0)$ \\
\hline Fimoxyclav & $S$ & $2(100.0)$ & $0(0.0)$ & $0(0.0)$ & $0(0.0)$ & $0(0.0)$ & $0(0.0)$ \\
\hline \multirow[t]{2}{*}{ Gentamicin } & S & $7(58.3)$ & $4(80.0)$ & $0(0.0)$ & $1(100.0)$ & $1(100.0)$ & $0(0.0)$ \\
\hline & $\mathrm{R}$ & $5(41.7)$ & $1(20.0)$ & $0(0.0)$ & $0(0.0)$ & $0(0.0)$ & $0(0.0)$ \\
\hline Levofloxacin & $S$ & $4(100.0)$ & $0(0.0)$ & $2(100.0)$ & $0(0.0)$ & $1(100.0)$ & $0(0.0)$ \\
\hline \multirow[t]{2}{*}{ Netilmicin } & S & $11(91.7)$ & $5(100.0)$ & $1(100.0)$ & $1(100.0)$ & $1(100.0)$ & $0(0.0)$ \\
\hline & $\mathrm{R}$ & 1 (8.3) & $0(0.0)$ & $0(0.0)$ & $0(0.0)$ & $0(0.0)$ & $0(0.0)$ \\
\hline \multirow[t]{2}{*}{ Nitrofurantoin } & $S$ & $7(53.8)$ & $2(50.0)$ & $1(100.0)$ & $1(100.0)$ & $1(100.0)$ & $0(0.0)$ \\
\hline & $\mathrm{R}$ & $6(46.2)$ & $2(50.0)$ & $0(0.0)$ & $0(0.0)$ & $0(0.0)$ & $0(0.0)$ \\
\hline \multirow[t]{2}{*}{ Penicillin } & $S$ & $0(0.0)$ & $0(0.0)$ & $1(100.0)$ & $1(100.0)$ & $0(0.0)$ & $0(0.0)$ \\
\hline & $\mathrm{R}$ & $1(100.0)$ & $0(0.0)$ & $0(0.0)$ & $0(0.0)$ & $0(0.0)$ & $0(0.0)$ \\
\hline Vancomycin & $\mathrm{S}$ & $0(0.0)$ & $0(0.0)$ & $1(100.0)$ & $1(100.0)$ & $0(0.0)$ & $0(0.0)$ \\
\hline
\end{tabular}


Table-VI

Antibiotic sensitivity pattern of the isolates

\begin{tabular}{llccc}
\hline Antibiotics & & Frequency & \multicolumn{2}{c}{ Percentage } \\
\cline { 3 - 5 } & & & Sensitive & Resistance \\
\hline Penicillin & Amoxicillin & 13 & 38.5 & 61.5 \\
& Cloxacillin & 1 & 100.0 & 0.0 \\
Cephalosporin & Ceftriaxone & 22 & 63.6 & 36.4 \\
& Cefuroxime & 10 & 60.0 & 40.0 \\
& Ceftazidime & 19 & 31.6 & 68.4 \\
Fluroquinolones & Cefixim & 18 & 44.4 & 55.6 \\
Aminoglycosides & Ciprofloxacin & 19 & 68.4 & 31.6 \\
& Amikacin & 22 & 86.4 & 13.6 \\
Glycopeptide & Gentamicin & 19 & 68.4 & 31.6 \\
Sulfonemide & Vancomycin & 2 & 100.0 & 0.0 \\
Nitrofuran & Co-trimoxazole & 13 & 50.0 & 50.0 \\
\hline & Nitrofuratoin & 21 & 57.1 & 42.9
\end{tabular}

\section{Discussion:}

Infection of the urinary tract is the most common bacterial infections encountered during pregnancy. The predominant bacterial isolates observed in this study were E. coli (76.0\%). This is similar to most other studies throughout the world where consistently $E$. coli has been consistently the predominant organisms causing UTI11-13. The major contributing factor for isolating higher rate of $\mathrm{E}$. coli due to urine stasis in pregnancy which favours for $E$. coli strain colonization ${ }^{14,15}$.

The sensitivity of amikacin was high (100\%) in this study, which is similar to other studies 8,16 . Sensitivity to nitrofurantoin and penicillin were low. No case of vancomycin resistant Staphlococcus aureus was seen in this study.

In a study done on 150 diabetic \& 250 non-diabetic patients A cross-sectional study was conducted in Lahore Pakistan, in which total of 400 patients were studied out of which 150 were diabetics and 250 were non-diabetics ${ }^{17}$. Patients with negative urine culture $(n=240)$ were excluded from the study and 160 patients with positive culture of UTIs of which 80 were diabetics and 80 were non-diabetics, included in this study. Clinical data were obtained from individual study participant with informed written consent using pre-tested questionnaire. According to the cleancatch procedure, midstream urine samples were collected and cultured for the diagnosis and susceptibility of bacteriuria. Out of 160 uropathogenic isolates, E. coli was found as a leading pathogen i.e. $46.25 \%$ followed by Candida spp. $30.62 \%$, S. Faecalis $15.62 \%$, P. aeruginosa $3.13 \%$, Pneumococcus. $1.25 \%$, MSSA $1.25 \%$, MRSA $0.63 \%$, Proteus spp. $0.63 \%$ and Vancomycin resistant enterococcus spp. $0.63 \%{ }^{17}$.

In a study in Nigeria on 100 diabetic patients with symptomatic and asymptomatic UTI, uropathogens were isolated in $40 \%$ of cases $^{18}$. The bacteria isolates were; Coagulase negative Staphylococci (CNS) $(37.5 \%)$, Escherichia coli $(24 \%)$, Klebsiella pneumoniae (12.5\%), Staphylococcus aureus (15\%) and Streptococcus spp (10\%). Esherichia coli and Klebsiella pneumoniae were highly resistant to most antibiotics used, while coagulase negative staphylococci, Staphylococcus aureus and Streptococcus were highly sensitive to most antibiotics used in this study.

\section{Conclusion:}

The finding revealed that UTI is a common problem in pregnanacy with GDM. Uropathogens were more resistant to penicillin. Self-medication including antibiotics and not completing the full course of antibiotics may be the reason. Common causative bacteria and their antibiotic sensitivity pattern are to be determined along with their safety to mother and fetus for effective treatment of urinary tract infection during pregnancy. 


\section{References:}

1. Feitosa DCA, Silva MG, Parada CMGL, accuracy of simple urine tests for diagnosis of urinary ttacr infections in loe-risk pregnant women. Rev Latino-am Enfermagem 2009; 17(4):507-13.

2. Abdullah AA, Al Moslih MI. Prevalence of asymptomatic bacteriuria in pregnant women in Sharjah, United Arab Emirates. East Mediterr Health J 2005; 11:5-6

3. Duarte G, Macrolin AC, Quintana SM, Cavalli RC. Urinary tract infection in pregnancy. Rev Bras Ginecol Obstet 2008; 30:93-100

4. Al Bash MR, Mathew M, Al Kharusi LA, Abu Heija . Symptomatic Urinary Tract Infection in Diabetic Pregnant Women, Effect of the Type of Diabetes and Glycemic Control. Saudi Journal of Medicine \& Medical Sciences. May 2016; 4(2):104-7.

5. Chandel LR, Kanga A, Thakur K, Mokta KK, Sood A, Chauhan S. Prevalance of pregnancy associated asymptomatic bacteriuria: A study done in a tertiary care hospital. J Obstet Gynaecol India 2012;62:511 4.

6. Onoh R, Umeora O, Egwuatu V, Ezeonu P, Onoh T. Antibiotic sensitivity pattern of uropathogens from pregnant women with urinary tract infection in Abakaliki, Nigeria. Infect Drug Resist 2013;6:225 33.

7. Emiru T, Beyene G, Tsegaye W, Melaku S. Associated risk factors of urinary tract infection among pregnant women at Felege Hiwot Referral Hospital, Bahir Dar, North West Ethiopia. BMC Res Notes 2013;6:292.

8. Valerius NH, Eff C, Hansen NE, Karle H, Nerup J, Soeberg B, et al. Neutrophil and lymphocyte function in patients with diabetes mellitus. Acta Med Scand 1982; 21(1):463-7.

9. Hasan MK, Nazimuddin K, Ahmed AKMS, Sarker RSC, Haque M, Musa AKM. Differences in a bacteriological and antibiotic sensitivity patterns in UTI among hospitalized diabetic and non diabetic patients. J Medicine 2007; 8: 10-3.

10. Tadesse A, Negash M, Ketema LS. Asymptomatic bacteriuria in pregnancy: assessment of prevalence, microbial agents and their antimicrobial sensitivity pattern in Gondar Teaching Hospital, North West Ethiopia. Ethiop Med J 2007; 45: 143-49.

11. Enayat K, Fariba F, Bahram N. Asymptomatic bacteriuria among pregnant women reffered to outpatient clinics in Sanandaj, Iran. Int. Braz J Urol 2008; 34: 699-707

12. Okonko IO, ljandipe LA, llusanya OA. Incidence of urinary tract infection (UTI) among pregnant women in Ibadan, South-Western Nigeria. Afr J Biotechnol 2009; 8: 6649-57.

13. Sescon NIC, Garingalao-Molina FD, Ycasiano CEJ, Saniel MC, Manalastas RM. Prevalence of Asymptomatic Bacteriuria and Associated Risk Factors in Pregnant Women. Phil J Microbiol Infect Dis 2003; 32: 63-69.

14. Imade PE, Izekor PE, Eghafona NO, Enabulele OI, Ophori E. Asymptomatic bacteriuria among pregnant women. North Am J Med Sci 2010;2: 263-66.

15. Moghadas AJ, Irajian G. Asymptomatic Urinary Tract Infection in Pregnant Women. Iranian J Pathol 2009; 4:105-08.

16. Girishbabu RJ, Prashanth HV, Chandrashekhar SC. Asymptomatic Bacteriuria in Patients with Diabetes Mellitus. National J Lab Med 2013; 2(2):11-13.

17. Zahra, N., Rehman, K., Aqeel, R., Parveen, A., \& Akash, M. S. H. (2016). Assessment of urinary tract infection and their resistance to antibiotics in diabetic and non-diabetic patients. Bangabandhu Sheikh Mujib Medical University Journal, 9(3), 151-155. https://doi.org/10.3329/ bsmmuj.v9i3.29511

18. Anejo-Okopi1JA, Okojokwu OJ, Ramyil SM, Bakwet PB, Okechalu J, Agada G, Bassi PA and Adeniyi SD. Bacterial and antibiotic susceptibility pattern of urinary tract infection isolated from asymptomatic and symptomatic diabetic patients attending tertiary hospital in Jos, Nigeria. Trends Med, 2017:17: 2-5 doi: 10.15761/TiM.1000108. 